\title{
Spectrometric Determination of Heavy Metals Present in Mango Fruit of Nepali Origin
}

\author{
Naresh Pant ${ }^{1}$, Anup Subedee ${ }^{1}$, Ram Bahadur Gharti ${ }^{2}$, Santu Shrestha ${ }^{*}$ \\ ${ }^{1}$ Amrit Campus, TU, Lainchour, Kathmandu, Nepal \\ ${ }^{2}$ Department of Mines and Geology, Kathmandu, Nepal \\ *Email: santu_shrestha@hotmail.com
}

(Received: 27 April, 2020, Received in revised form: 2 August, 2020, Accepted:10 August, 2020, Available online)

\section{Highlights}

- Fifteen fully ripe mango samples were sampled from local market of Kathmandu.

- Extracted pulp of mango was taken and oven dried at $150{ }^{\circ} \mathrm{C}$ for 24 hours.

- The digest samples were analyzed for heavy metals (Fe, $\mathrm{Zn}, \mathrm{Co}, \mathrm{Pb}$ and $\mathrm{Ni}$ ) using the AAS.

- The concentration of the Lead $(\mathrm{Pb})$ was found below the detection limit of the instrument used.

\begin{abstract}
Quantitative determination of heavy metals; $\mathrm{Fe}, \mathrm{Zn}, \mathrm{Co}, \mathrm{Pb}$ and $\mathrm{Ni}$ in Mango fruit of Nepali origin, locally sourced was carried out. Fifteen Mango samples were collected by random sampling method, converted into analyte sample by standard method and analyzed by using Atomic absorption spectrometric method. The amount of heavy metals Fe, Zn, Co and Ni present in sample was, $0.570 \pm 0.48,0.510 \pm 0.031,0.431 \pm 0.021,0.106 \pm 0.003 \mathrm{mg} / \mathrm{kg}$ respectively. The results indicated the concentration of $\mathrm{Zn} \& \mathrm{Co}$ were higher (WHO $0.320 \& 0.05$ ), and the concentration of Nickel (Ni) was below the maximum permissible limit issued by WHO. The concentration of the Lead $(\mathrm{Pb})$ was found below the detection limit of the instrument used.
\end{abstract}

Graphical Abstract

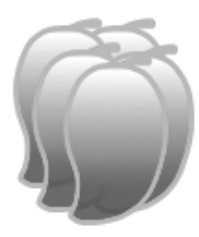

Mango Fruit

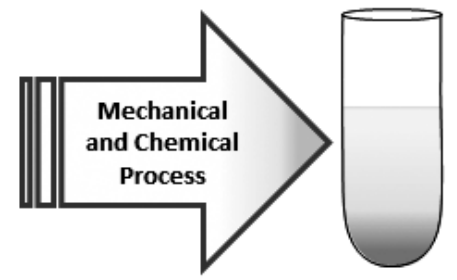

Analyte Solution

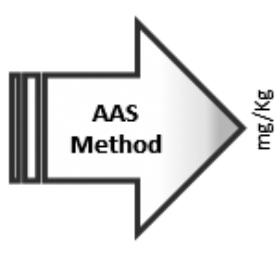

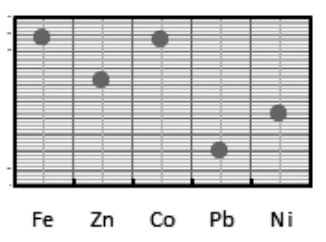

Heavy Metal Content
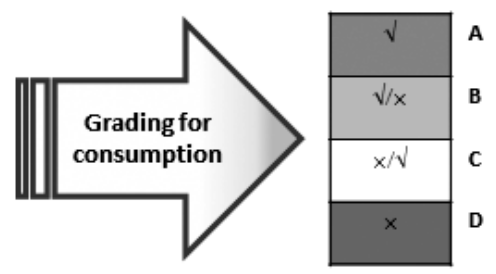

Health Risk

Key words: AAS method, Concentration, Heavy Metals, Mango.

${ }^{*}$ Corresponding author 


\section{INTRODUCTION}

Quality of food has been a main concern globally regarding the effect associated with the intake of food stuffs contaminated by heavy metals. Food is the major source of toxic elements in trace amount by human being. Fruits are especially used in raw form as staple part of food (Farid and Enani, 2010). Regular consumption of fruit is essential in providing nutrients to the human body. Fruits are good sources of dietary fiber, minerals and phytochemicals. Phytochemicals function as antioxidants, phytoestrogens, and anti-inflammatory agents (Slavin and Lloyd, 2012). Different types of antioxidant components such as vitamin E, carotenoids, phenolic compounds, ascorbic acid, phytosterols are found in different fruits and vegetables (Ravimannan and Nisansala, 2017). Fruits and vegetables intake lowers tendency of cardiovascular disease and obesity. Mango pulp are good source of antioxidants (Rocha et al., 2007). Mango (Mangifera indica) kernel has been reported for phytochemicals and antioxidant activity (Arogba et al., 2012). Fruits like Mango may contain heavy metals as they receive minerals from soil and water. Some heavy metals are essential but some are toxic above certain limit (Doherty et al., 2014). Many literatures have been reported about the determination of heavy metals in fruit samples. Tegegne et al., 2015, had determined heavy metals (Zn, $\mathrm{Fe}, \mathrm{Cu}, \mathrm{Mn}, \mathrm{Co}, \mathrm{Ni}, \mathrm{Cr}, \mathrm{Pd}$ and $\mathrm{Cd}$ ) in selected edible fruits namely avocado, mango, papaya, pineapple, orange and banana purchased from local markets of Ethiopia. The concentrations of zinc $(\mathrm{Zn})$, copper( $\mathrm{Cu})$, iron( $\mathrm{Fe})$, chromium $(\mathrm{Cr})$, manganese $(\mathrm{Mn})$, cobalt $(\mathrm{Co})$ and nickel(Ni) in apple, orange and mango fruit juice from local market of Saudi Arabia has been measured (Farid and Enani, 2010). The contents of lead $(\mathrm{Pb})$, copper $(\mathrm{Cu})$, Iron $(\mathrm{Fe})$, and manganese $(\mathrm{Mn})$ in Mango fruit of Nigeria has been measured by using AAS and found within the permissible level given by WHO (Chata et al., 2018). The concentration of Ni, $\mathrm{Cd}, \mathrm{Cr}, \mathrm{Mn}$ and $\mathrm{Pb}$ in all samples plum, orange, mango and strawberry has been measured (Anastácio et al., 2018). Similarly, Dehelean and Magdas in 2013 measured the heavy Metal Content of Some common Commercialy available Fruit Juices (apple, peach, apricot, orange, kiwi, pear, pineapple, and multi fruit) on Romanian market.

National and international regulations on food safety have set the optimum levels of heavy metals in food. Some of heavy metals have been identified to effect in greater extent to the nutritive values of agricultural products. So the assurance of food quality regarding heavy metal concentration is important for good health. Determination of such heavy metals is common practice all over the world regarding the fruit/food safety concern.

Mango is native to south Asia, which is one of the most widely cultivated fruit in the tropics. It is the national fruit of both Pakistan and India (GIMA, 2013) with India having the highest production in the world (Ahmed et al, 2014). The fruit is rich in antioxidants and reduces the risk of cardiac disease, effective in anti cancer and anti viral activities (Daud et al., 2010). Composition of mango fruits differ chemically regarding different cultivars, and area of production. Storage techniques using coatings and packaging materials extend the storage life with appreciable retention of physical, chemical and sensory parameters (Hulme, 1971; Abbasi et al., 2011). In Nepal, it is reported that about $56 \%$ of the total summer fruit area is occupied by mango whereas it covers $42 \%$ of total summer fruit production. Eastern and central region of Nepal are highest production area. Sarlahi, Siraha, Saptari, Rautahat and Jhapa are major mango production districts of Nepal (Pandey et al., 2017). There is no sufficient studies found on the heavy metal concentrations in the fruits in Nepal, though regular monitoring and assessment of concentration of heavy metals in the vegetables and fruits has been reported in the developed and some developing countries. The heavy metal intake by people through the fruits and vegetables is of major concern as it has direct impact on the health. The determination of concentration of heavy metals in the mango would help to know the health impact of consuming this fruit. So, this study is focused to investigate the concentrations of heavy metals in Mango of Nepali origin.

\section{Materials and Methods}

\section{Sample collection and pulp extraction}

Fifteen fully ripe mango samples were sampled from local market of Kathmandu by random sampling method, washed with double distilled water and dried. The pulp of mango was separated from kernel and skin by stainless steel knife and stored in refrigerator below $4^{\circ} \mathrm{C}$.

\section{Sample digestion}

Extracted pulp of mango was dried in oven at $150{ }^{\circ} \mathrm{C}$ for 24 hours until it became brittle and crisp. Then this solid mass was grounded by using mortar and pestle, which was washed with acid. Exact $3.0 \mathrm{~g}$ of each of the grounded powder sample was heated in silica crucible in muffle furnace at $450{ }^{\circ} \mathrm{C}$ for $4 \mathrm{hrs}$. Heated samples were taken out, cooled and treated with $2.5 \mathrm{~mL}$ 
of concentrated $\mathrm{HNO}_{3}$ and covered with watch glass, which was further heated at a temperature of $90{ }^{\circ} \mathrm{C}$ for $1 \mathrm{hr}$ and allowed cooling. Then $5 \mathrm{~mL}$ of $9.25 \mathrm{HCl}$ was added to dissolve the sample and digested using hot plate. Further the digest was cooled, to which $20 \mathrm{~mL}$ of double distilled water added and filtered using Whatman No. 41 filter paper. The filtrate obtained was diluted up to $50 \mathrm{~mL}$ by adding double distilled water. All the samples were prepared three times to minimize the chances of error.

\section{Determination of heavy metals}

The digest samples were analyzed for heavy metals ( $\mathrm{Fe}, \mathrm{Zn}, \mathrm{Co}, \mathrm{Pb}$ and $\mathrm{Ni}$ ) using the AAS (SHIMAZDU- 7000, Japan). The calibration of the instrument (AAS) was done with calibration blank and three series of calibrating standard solution. For each of five heavy metals - Iron (Fe), Zinc ( $\mathrm{Zn})$, Cobalt ( $\mathrm{Co}$ ), Lead ( $\mathrm{Pb})$ and Nickel (Ni), four standard solutions of various concentrations $(0.5 \mathrm{ppm}, 1 \mathrm{ppm}, 2 \mathrm{ppm}$ and $5 \mathrm{ppm})$ were prepared. The absorbance of all standard solutions of various concentrations $(0.5 \mathrm{ppm}$, $1 \mathrm{ppm}, 2 \mathrm{ppm}$ and $5 \mathrm{ppm}$ ) for all the five metals ( $\mathrm{Fe}, \mathrm{Zn}, \mathrm{Co}, \mathrm{Pb}$ and $\mathrm{Ni}$ ) were measured and a calibration curve was prepared as shown in Figure 1, then the absorbance of the sample solutions were measured to determine the concentration of different metals (Fe, $\mathrm{Zn}, \mathrm{Co}, \mathrm{Pb}$ and $\mathrm{Ni}$ ).

\section{Data analysis}

Heavy metal concentrations in the mango fruit were analyzed in triplicate and compared with maximum permissible limit of WHO for each metal. The mean value and standard deviations of concentrations of metal were determined.

\section{Results and Discussion}

The mean concentration of the metals ( $\mathrm{Fe}, \mathrm{Zn}, \mathrm{Co}, \mathrm{Pb}$ and $\mathrm{Ni}$ ) in mango fruit collected from local market of Kathmandu is presented in Table 1. The results of triplicate data are expressed as mean \pm standard deviation (SD).

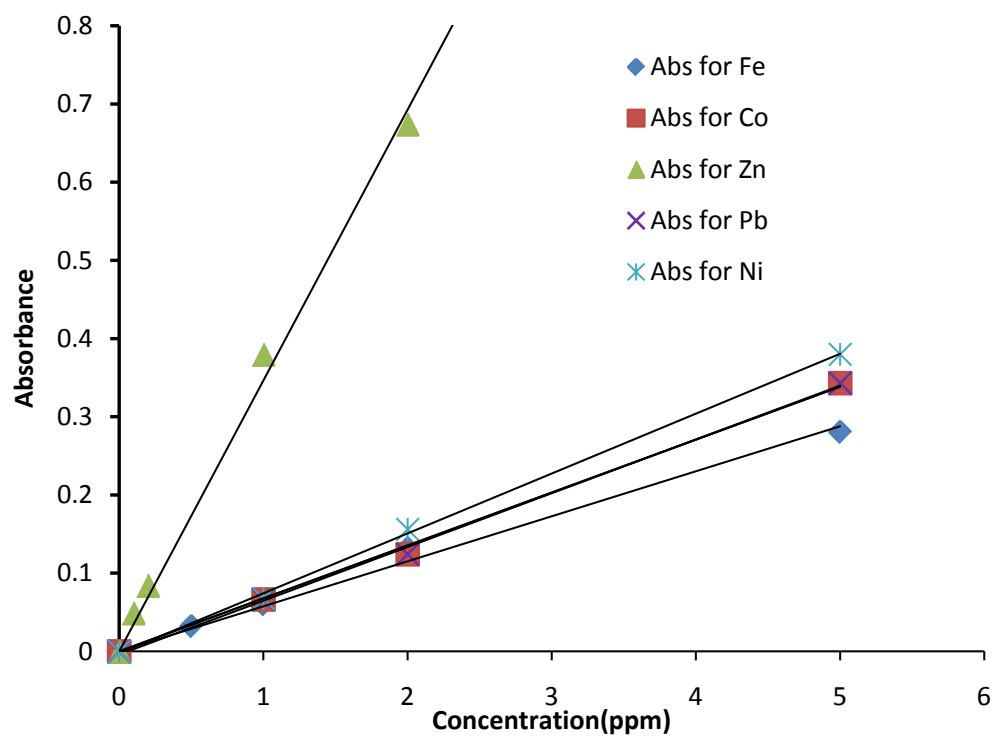

Fig 1: calibration curve for heavy metals (Fe, $\mathrm{Co}, \mathrm{Zn}, \mathrm{Pb}$ and $\mathrm{Ni}$ ) to be measured.

\section{Iron}

Iron is one of the important component of the human blood. The deficiency of iron in the blood can lead to the serious health problems including anemia. Results showed that the concentration of iron in the mango fruit is $0.570 \pm 0.48 \mathrm{mg} / \mathrm{kg}$, which is within the maximum permissible limit of WHO $(0.80) \mathrm{mg} / \mathrm{kg}$.

\section{Zinc}

Zinc is an essential element of the body and component of many coenzymes, essential for synthesis of protein, DNA, RNA and insulin. The results show that the concentration of zinc in the mango fruit is $0.510 \pm 0.031 \mathrm{mg} / \mathrm{kg}$ which is higher than the maximum permissible limit of WHO $(0.30) \mathrm{mg} / \mathrm{kg}$. 


\section{Cobalt}

Cobalt is the integral part of vitamin B-12. Cobalt is also involved in the production of red blood cells, antibacterial and antiviral compounds. But excessive intake of the cobalt may cause the high production of red blood cells. The concentration of the cobalt found in the mango fruit is $0.431 \pm 0.021 \mathrm{mg} / \mathrm{kg}$ which is higher than the maximum permissible limit of WHO.

\section{Lead}

Lead may enter the body through air, water and food. Lead cannot be removed from fruit and vegetable by washing with water. The concentration of lead in the mango fruit was below the detectable level of the instrument which shows that either lead is absent in the sample or present in trace amount.

\section{Nickel}

Nickel is required in small amount for the body and plays important role in the production of insulin. Its deficiency causes disorder in the functioning of the liver. The concentration of nickel found in the sample is $0.106 \pm 0.003 \mathrm{mg} / \mathrm{kg}$ which is below the maximum permissible limit of WHO.

Among the metals analyzed the concentrations of zinc and cobalt were found higher than the maximum permissible limit of WHO whereas the concentration of iron, lead and nickel were within the acceptable limit. The higher concentration of the metals may be due to sources of production as it comes from different region of the country, contamination during transportation, exposure to environmental pollution, pollutants found in irrigation water, soil. Furthermore agronomic practices such as application of fertilizers, pesticides could be also responsible for the accumulation of these metals. The high concentration of cobalt may be due to exposure of production region to industrial wastages, dumpsites containing decomposed batteries. The data in Table 1 shows the concentration of heavy metals in mango fruit in part per million and reported as $\mathrm{mg} / \mathrm{kg}$ and compared with WHO maximum permissible limit. Comparative bar diagram of $\mathrm{Fe}, \mathrm{Zn}, \mathrm{Co}, \mathrm{Pb}$ and $\mathrm{Ni}$ with $\mathrm{WHO}$ maximum permissible limit for mango fruit is shown in Figure 2.

Table 1 Average concentration of Heavy Metals (meanSD, $n=15, \mathrm{mg} / \mathrm{kg}$ or ppm dry weight) in mango.

\begin{tabular}{|c|c|c|}
\hline Heavy Metals & Mango Samples & Permissible Concentration Limit by WHO (ppm) \\
\hline $\mathrm{Fe}$ & $0.570 \pm 0.48$ & 0.80 \\
\hline $\mathrm{Zn}$ & $0.510 \pm 0.031$ & 0.320 \\
\hline $\mathrm{Co}$ & $0.431 \pm 0.021$ & 0.05 \\
\hline $\mathrm{Pb}$ & -- & 0.3 \\
\hline $\mathrm{Ni}$ & $0.106 \pm 0.003$ & 1.40 \\
\hline
\end{tabular}

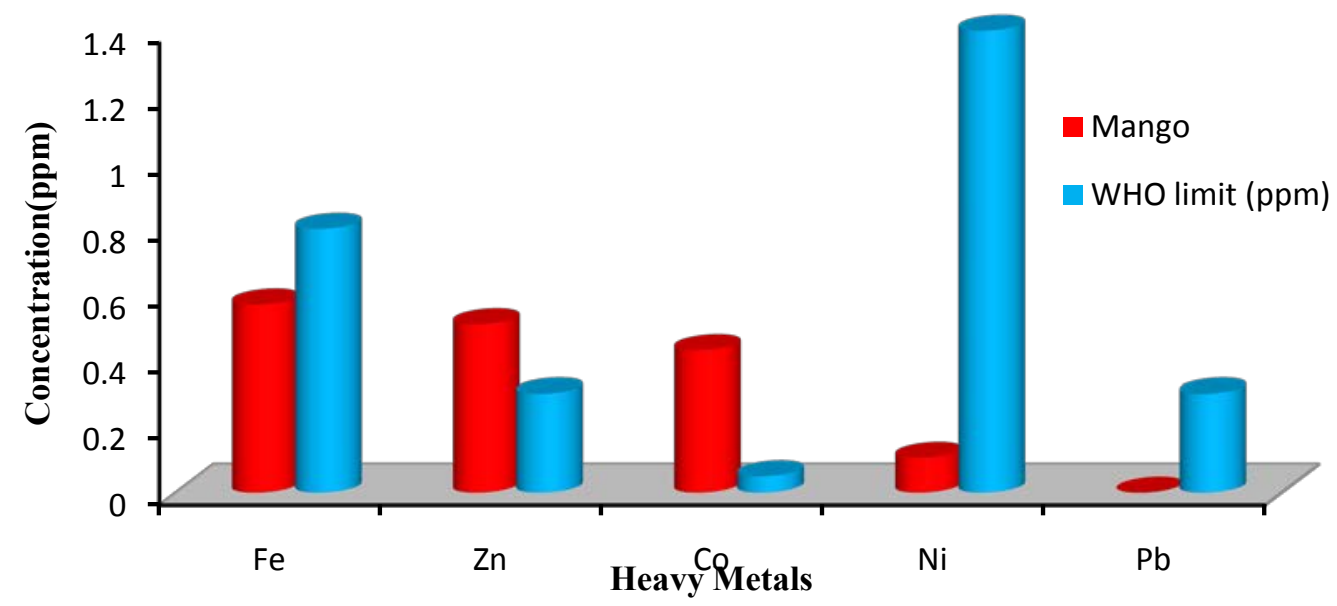

Figure 2 Concentration of $\mathrm{Fe}, \mathrm{Zn}, \mathrm{Co}, \mathrm{Pb}$ and $\mathrm{Ni}$ in Mango samples 


\section{Conclusions}

The concentration of heavy metals in the Mango samples were determined by using Atomic absorption spectroscopy (SHIMAZDU- 7000, Japan). The results obtained reveals that among the essential metals, concentration of each $\mathrm{Zn}$ and $\mathrm{Co}$ in the mango sample were higher but all other metals among measured lies within the maximum permissible limit of WHO. High concentration of the metals may be due to exposure to polluted environment of the region of production, contamination during transportation, the composition of the soil, irrigation water, and storage practices. In addition agronomic practices such as fertilizers, pesticides, and ripening agent used could also be reason for it. The results indicate that on consumption of mango, high amount of $\mathrm{Zn}$ and $\mathrm{Co}$ is also consumed. The study shows that further study should be carried out to identify the exact source of contamination regarding area of production, cultivars, irrigation sources and agronomic practices. If reproducible data are obtained then the matter is very serious as mango is highly consumable summer fruit all over the country. Regular monitoring of heavy metals in fruits and vegetables supplied to the market is essential to reduce the health risk of the people. Government should set up a regulatory body for continuous monitoring of heavy metals in fruit and vegetables.

\section{Acknowledgements}

Authors are grateful to the Department of Chemistry, Amrit Campus and Department of Mines and Geology for laboratory support.

\section{References}

Abbasi, K.S., Anjum, N., Sammi, S., Masud, T. and Ali, S (2011). Effect of coatings and packaging material on the keeping quality of mangoes (Mangifera indica L.) stored at low temperature. Pakistan J. Nutr. 10(2): 129-138.

Ahmed, K.O. and Ahmed, E.T.S. (2014). Determination of Optimum Maturity Index of Mango Fruits (Mangifera indica, L.) in Darfur. Agriculture and Biology Journal of North America. 5(2): 97-103.

Anastácio, M., Marreilha dos Santos, A.P., Aschner, M. and Mateus, L. (2018). Determination of trace metals in fruit juices in the Portuguese market. Toxicology reports. 5: 434-439.

Arogba, S.S. and Omede, A. (2012). Comparative Antioxicant Activity of Processed Mango (Mangiferaindica) and Bush Mango (Irvingiagabonensis) Kernels. Nigerian Food Journal, 30(2): 17-21.

Chata, D.M., Iliya, A.Y., Chidawa, M.S., Emmanuel, M.B., Juliana, O.O. and Chinuzor, E.K. (2018). Determination of Heavy Metals in Four Mango Fruit Varieties Sold in Minna Modern Market, Niger State, Nigeria. International Journal of Biological and Environmental Engineering, 1: 24-29.

Daud, N.H., Aung, A.C., Hewavitharana, A.K., Wilkinson, A.S., Pierson, J.T., Roberts-Thomson, S.J., Shaw, P.N., Monteith, G.R., Gidley, M.J and Parat, M.O (2010). Mango extracts and the mango component mangiferin promote endothelial cell migration. J. Agric. Food Chem. 58(8): 5181-5186. (Doi: 10.1021/jf100249s).

Dehelean, A. and Magdas, D.A. (2013). Analysis of mineral and heavy metal content of some commercial fruit juices by inductively coupled plasma mass spectrometry. The Scientific World Journal. https://doi.org/10.1155/2013/215423

Doherty, V.F., Sogbanmu, T.O., Kanife, U.C. and Wright, O., (2012). Heavy metals in vegetables collected from selected farm and market sites in Lagos, Nigeria. Journal of Environmental Science and Toxicology. 1(6): 137-142.

Farid, S.M. and Enani, M.A. (2010). Levels of trace elements in commercial fruit juices in Jeddah, Saudi Arabia. Medicine Journal Islamic World Academy Science. 18(1): 31-38.

Government of India Ministry of Agriculture (GIMA) (2013). (Department of Agriculture \& Cooperation) Directorate of Marketing \& Inspection Branch Head Office, Nagpur. Post-Harvest Profile of Mango. 
Hassan, A. S. M., Abd El-Rahman, T. A. \& Marzouk, A. S. (2014). Estimation of Some Trace Metals in Commercial Fruit Juices in Egypt. International Journal of Food Science and Nutrition Engineering 4(3), 66-72.

Hossieni, H. (2011). Determination of Zinc (II) Ions in Waste Water Sample by Novel Zinc Sensor Based on Newly Synthesized Schiff's Base. Material Science and Engineering journal, 31, 428-433.

Hulme, A. C (1971). The Mango. In: Hulme AC (ed) The biochemistry of fruits and their products, vol. 2, London, New York: Academic Press, pp: 233-254.

Krejpcio, Z, Sionkowiski, S. \& Bartela, J. (2005). Safety of Fresh Fruits and Juices Available on Polish Markets as Determined by Heavy Metal Residues. Polish Journal of Environmental Studies. 2(2-3), 12-13.

Pandey, G., Basnet, S., Pant, B., Bhattarai, K., Guawali, B., \& Tiwari, A. (2017). An Analysis of Vegerables and Fruits Production Scenario in Nepal. Asian Research Journal of Agriculture, 6(3), 1-10. https://doi.org/10.9734/ARJA/2017/36442

Rahimzadeh, M. \& Rastegar, S. (2017). Heavy Metals Residue in Cultivated Mango Samples from Iran. Journal of Food Quality and Hazards Control 4, 29-31.

Ravimannan, N. \& Nisansala, A. (2017). Study on Antioxidant Activity in Fruits and Vegetables. Review. International Journal of Advanced Research in Biological Sciecnces. 4 (3): 93-101. DOI: http://dx.doi.org/10.22192/ijarbs.

Rocha, R. S.M., Queiroz, J.H, Lopes R. d. Q. M.E., Campos, F.M., Pinheiro, S. H. M. (2007) Antioxidant in Mango (Mangifera indica L.) Pulp. Plant Foods for Human Nutrition.; 62 (1):13 $\square$ 17. doi:10.1007/s11130-006-0035-3

Slavin, J.L. \& Lloyd, B. (2012). Health Benefits of fruits and vegetables. Advances in Nutrition 3 (4): $506-516$. doi: 10.3945/ an. 112.002154

Tegegne, W.A. (2015). Analysis of Heavy Metal Levels in Some Edible Fruits from Selected Markets in Ethiopia. Journal of Modern Chemistry \& Chemical Technology. 6(1): 1-8. 